\title{
EXPERIMENTAL STUDIES ON THE ULTIMATE MOMENT OF CONCRETE FILLED SQUARE STEEL TUBULAR BEAM-COLUMNS
}

\author{
By MASAHIDE TOMII* and KENJI SAKINO** \\ Members of A.I.J.
}

\section{INTRODUCTION}

Tubular sections, either empty or filled with concrete, are being increasingly used as structural members. When a tube is acting as a compression member, filling the tube with concrete is advantageous because it increases the load-carrying capacity without increasing the size of the column.

Considerable work has been done with regard to the behavior of concentrically loaded concrete filled steel tubular columns. In practice most structural members subjected to axial load are also subjected to combined shearing force and bending moment. Due to the large shear capacity of the concrete filled steel tubular columns, they predominantly fail in flexure. Therefore, it is important to structural design to investigate their inelastic flexural behavior.

Significant researches on circular section beam-columns have been carried out by Furlong ${ }^{1}$, Knowles and $\mathrm{Park}^{2)}$, Sen ${ }^{3)}$ and Yamada, Sakae and Kondoh'). But there were few investigations on square section beam-columns. Furlong ${ }^{1)}$ tested 17 square sections under various amounts of axial loads, which were held constant while bending moments were increased until the columns ceased to sustain the axial loads. However, the moment-thrust-curvature relationships were not given, but the axial load and the moment at failure were tabulated. There was a lack of information about the inelastic behavior of concrete filled square steel tubular beam-columns.

The objective of this investigation is to test a number of square sections under fixed axial loads and increasing uniform bending moments in order to make clear the moment-thrust-curvature characteristics. The objective also includes the proposition of rational simple method for estinating the ultimate moment.

\section{EXPERIMENTAL PROGRAM}

Test specimens : 36 -specimens with $10 \mathrm{~cm} \times 10 \mathrm{~cm}$ cross sections were tested. These were divided into 4 series, I to IV. Each test series consisted of 2 concentrically loaded stub columns (column length was $30 \mathrm{~cm}$ ) and 7 columns subjected to axial loads and bending moments (see Table 1). The

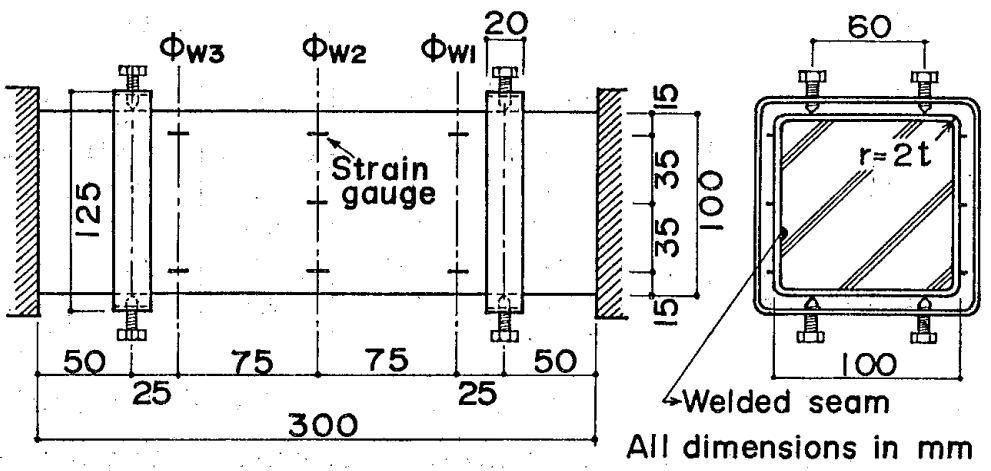

Fig. 1 Details of the test specimen and locations of strain gauges

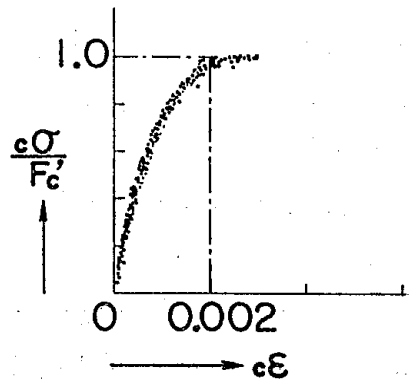

Fig. 2 Stress strain relations for concrete

\footnotetext{
* Professor of Structural Engineering, Kyushu University, D. Eng.
}

** Research Assistant, Kyushu University, M. Eng. 
Table 1 Properties of specimen and test results

Concentrically loaded columns

\begin{tabular}{|c|c|c|c|c|c|c|c|c|c|c|c|}
\hline Series & Specimen & $\begin{array}{c}\text { Steel tube } \\
\text { used }^{*}\end{array}$ & $\begin{array}{c}F_{c^{\prime}} \\
\left(\mathrm{kg} / \mathrm{cm}^{2}\right)\end{array}$ & $\begin{array}{l}{ }_{s} N_{0} \\
(\mathrm{t})\end{array}$ & $\begin{array}{l}N_{0}^{\prime} \\
(t)\end{array}$ & $\begin{array}{l}N_{0} \\
\text { (t) }\end{array}$ & ${ }_{s} N_{0} / N_{0}$ & $\begin{array}{c}\text { Age at test } \\
\text { (days) }\end{array}$ & $\begin{array}{l}N_{u} \\
(\mathbf{t})\end{array}$ & $N_{u} / N_{0^{\prime}}$ & $N_{u} / N_{0}$ \\
\hline I & $\begin{array}{l}\mathrm{I}-\mathrm{A} \\
\mathrm{I}-\mathrm{B}\end{array}$ & $2-1$ & 326 & 17.3 & 46.9 & 52.8 & 0.33 & $\begin{array}{l}48 \\
49\end{array}$ & $\begin{array}{l}50.7 \\
50.8\end{array}$ & $\begin{array}{l}1.08 \\
1.08\end{array}$ & $\begin{array}{l}0.96 \\
0.96\end{array}$ \\
\hline II & $\frac{\text { II-A }}{\text { II }-\mathrm{B}}$ & $2-3$ & 218 & 29.2 & 49.3 & 53.3 & 0.55 & $\begin{array}{l}44 \\
44\end{array}$ & $\begin{array}{l}52.1 \\
52.0\end{array}$ & $\begin{array}{l}1.06 \\
1.05\end{array}$ & $\begin{array}{l}0.98 \\
0.98\end{array}$ \\
\hline III & $\begin{array}{l}\text { III-A } \\
\text { III-B }\end{array}$ & $3-2$ & 210. & 33.4 & 52.0 & 55.7 & 0.64 & $\begin{array}{l}39 \\
39\end{array}$ & $\begin{array}{l}53.9 \\
53.8\end{array}$ & $\begin{array}{l}1.04 \\
1.03\end{array}$ & $\begin{array}{l}0.97 \\
0.97\end{array}$ \\
\hline IV & $\begin{array}{l}\text { IV-A } \\
\text { IV-B }\end{array}$ & $4-1$ & 202 & 46.0 & 63.0 & 66.4 & 0.69 & $\begin{array}{l}37 \\
37\end{array}$ & $\begin{array}{l}68.0 \\
67.9\end{array}$ & $\begin{array}{l}1.08 \\
1.08\end{array}$ & $\begin{array}{l}1.02 \\
1.02\end{array}$ \\
\hline
\end{tabular}

Columns subjected to axial load and bending moment

\begin{tabular}{|c|c|c|c|c|c|c|c|c|c|c|c|}
\hline \multirow{2}{*}{ Series } & \multirow{2}{*}{ Specimen } & \multirow{2}{*}{$\begin{array}{l}\text { Steel tube } \\
\text { used }^{*}\end{array}$} & \multirow{2}{*}{$\begin{array}{c}F_{c^{\prime}} \\
\left(\mathrm{kg} / \mathrm{cm}^{2}\right)\end{array}$} & \multirow{2}{*}{$\begin{array}{l}{ }_{s} N_{0} \\
(\mathrm{t})\end{array}$} & \multirow{2}{*}{$\begin{array}{l}N_{0}^{\prime} \\
(t)\end{array}$} & \multirow{2}{*}{$\begin{array}{l}N_{0} \\
(\mathbf{t})\end{array}$} & \multicolumn{3}{|c|}{ Axial load } & \multirow{2}{*}{$\begin{array}{c}\text { Age at test } \\
\text { (days) }\end{array}$} & \multirow{2}{*}{$\begin{array}{c}M_{u} \\
(\mathrm{t} \cdot \mathrm{cm})\end{array}$} \\
\hline & & & & & & & $\begin{array}{c}N \\
(t)\end{array}$ & $N / N_{0}^{\prime}$ & $N / N_{0}$ & & \\
\hline \multirow{7}{*}{ I } & $I-0$ & \multirow{7}{*}{$2-1$} & 245 & 17.3 & 39.6 & 44.1 & 0 & 0 & 0 & 46 & 73 \\
\hline & $I-1$ & & 390 & 17.3 & 52.8 & 59.9 & 7.8 & 0.15 & 0.13 & 386 & 104 \\
\hline & $I-2$ & & 390 & 17.3 & 52.8 & 59.9 & 16.1 & 0.30 & 0.27 & 388 & 114 \\
\hline & $\mathrm{I}-3$ & & 390 & 17.3 & 52.8 & 59.9 & 19.5 & 0.37 & 0.33 & 393 & 114 \\
\hline & $I-5$ & & 390 & 17.3 & 52.8 & 59.9 & 27.3 & 0.52 & 0.46 & 395 & 117 \\
\hline & $I-6$ & & 374 & 17.3 & 51.3 & 58.1 & 33.7 & 0.66 & 0.58 & 356 & 91 \\
\hline & $I-6^{\prime}$ & & 374 & 17.3 & 51.3 & 58.1 & 33.7 & 0.66 & 0.58 & 358 & 84 \\
\hline \multirow{7}{*}{ II } & II -0 & $2-2$ & 220 & 27.2 & 47.3 & 51.3 & 0 & 0 & 0 & 36 & 112 \\
\hline & II -1 & $2-2$ & 220 & 27.2 & 47.3 & 51.3 & 4.7 & 0.10 & 0.09 & 35 & 126 \\
\hline & II -2 & $2-3$ & $220^{\circ}$ & 29.2 & 49.3 & 53.3 & 9.4 & 0.19 & 0.18 & 34 & 132 \\
\hline & II-3 & $2-3$ & 220 & 29.2 & 49.3 & 53.3 & 14.1 & 0.29 & 0.26 & 34 & 129 \\
\hline & III-4 & $2-4$ & 220 & 25.2 & 45.3 & 49.3 & 18.8 & 0.42 & 0.38 & 34 & 120 \\
\hline & II -5 & $2-4$ & 220 & 25.2 & 45.3 & 49.3 & 23.6 & 0.52 & 0.48 & 35 & 109 \\
\hline & III-6 & $2-4$ & 220 & 25.2 & 45.3 & 49.3 & 28.3 & 0.62 & 0.57 & 35 & 93 \\
\hline & III-0 & $3-1$ & 210 & 33.4 & 52.0 & 55.7 & 0 & 0 & 0 & 38 & 143 \\
\hline & III-1 & $3-1$ & 210 & 33.4 & 52.0 & 55.7 & 5.2 & 0.10 & 0.09 & 37 & 149 \\
\hline & III -2 & $3-1$ & 210 & 33.4 & 52.0 & 55.7 & 10.4 & 0.20 & 0.19 & 37 & 155 \\
\hline & III -3 & $3-2$ & 210 & 33.4 & 52.0 & 55.7 & 15.6 & 0.30 & 0.28 & 37 & 148 \\
\hline & III -4 & $3-2$ & 210 & 33.4 & 52.0 & 55.7 & 20.8 & 0.40 & 0.37 & 37 & 136 \\
\hline & $\prod-5$ & $3-2$ & 210 & $33: 4$ & 52.0 & 55.7 & $26: 0$ & 0.50 & 0.47 & 38 & 127 \\
\hline & III-6 & $3-3$ & 210 & 33.4 & 52.0 & 55.7 & 31.2 & 0.60 & 0.56 & 38 & 110 \\
\hline \multirow{7}{*}{ IV } & $\mathrm{IV}-0$ & $4-1$ & 190 & 46.0 & 62.0 & 65.2 & 0 & 0 & 0 & 30 & 187 \\
\hline & $\mathrm{IV}-1$ & $4-1$ & 190 & 46.0 & 62.0 & 65.2 & 6.3 & 0.10 & 0.10 & 30 & 194 \\
\hline & $\mathrm{IV}-2$ & $4 \div 1$ & $\therefore 190$ & 46.0 & 62.0 & 65.2 & 12.6 & 0.20 & 0.19 & 31 & 192 \\
\hline & $I V-3$ & $4-2$ & .190 & 46.1 & 62.1 & 65.3 & 18.9 & 0.30 & 0.29 & 31. & 186 \\
\hline & $\mathrm{IV}-4$ & $4-2$ & 202 & 46.1 & 63.1 & 66.5 & 25.6 & 0.41 & 0.38 & 34 & 177 \\
\hline & $\mathrm{IV}-5$ & $4-2$ & 202 & 46.1 & 63.1 & 66.5 & 32.0 & 0.51 & 0.48 & 34 & 161 \\
\hline & IV -6 & $4-3$ & 202 & 46.7 & 63.7 & 67.1 & 38.3 & 0.60 & 0.57 & 35 & 143 \\
\hline
\end{tabular}

* See Table 3.

Note : ${ }_{s} N_{0}={ }_{s} A_{s} \sigma_{y} . \quad N_{0}{ }^{\prime}={ }_{s} A_{s} \sigma_{y}+{ }_{c} A F_{c}{ }^{\prime} . \quad N_{0}={ }_{s} A_{s} \sigma_{y}+{ }_{c} A_{c} \sigma_{B} . \quad{ }_{c} \sigma_{B}=1.2 F_{c}{ }^{\prime}$

$F_{c^{\prime}}=$ compressive strength of expansive concrete cylinder cured in the mould.

$c^{\sigma} B=$ compressive strength of concrete core. $M_{\mathfrak{u}}=$ experimental ultimate moment.

$N_{u}=$ experimental ultimate strength of the concentrically loaded column.

variable parameters between the series were the

Table 2 Mix proportion of concrete tube thickness and material properties, and the variable between the specimens in each series was the axial load. The external dimensions of the specimen are shown in Fig. 1.

The concrete was compacted by means of a vibrator during and after the placing. Specimens

\begin{tabular}{c|c|c|c|c|c|c}
\hline $\begin{array}{c}\text { Test } \\
\text { series }\end{array}$ & $\begin{array}{c}W / C \\
(\%)\end{array}$ & $\begin{array}{c}\text { Water } \\
\left(\mathrm{kg} / \mathrm{m}^{\mathrm{g}}\right)\end{array}$ & $\begin{array}{c}\text { Expansive } \\
\text { cement } \\
\left(\mathrm{kg} / \mathrm{m}^{8}\right)\end{array}$ & $\begin{array}{c}\text { Sand } \\
\left(\mathrm{kg} / \mathrm{m}^{8}\right)\end{array}$ & $\begin{array}{c}\text { Coarse } \\
\text { aggregate } \\
\left(\mathrm{kg} / \mathrm{m}^{8}\right)\end{array}$ & $\begin{array}{c}\text { Slump } \\
(\mathrm{cm})\end{array}$ \\
\hline I & 57 & 189 & 333 & 933 & 921 & 4.0 \\
II & 69 & 237 & 343 & 925 & 942 & 5.5 \\
III & 71 & 237 & 333 & 925 & 942 & 6.3 \\
IV & 70 & 226 & 321 & 925 & 942 & 6.7 \\
\hline
\end{tabular}
of the same series were filled from one batch except for those of series I. A number of $10 \mathrm{~cm} \times 20 \mathrm{~cm}$ test cylinders were taken from each batch for determination of the concrete properties. "The concrete cylinders and both ends of the specimens were capped with a thin layer of neat cement and were flush with the steel surface. The specimens and concrete cylinders in the moulds were then stored at ambient temperature and humidity until testing. 
Materials : Crushed coarse aggregate of $20 \mathrm{~mm}$ maximum size and sand of $2.5 \mathrm{~mm}$ maximum size were used in making the concrete. The concrete mix ratios by weight are shown in. Table 2 . Expansive cement containing 15 percent of expansive component was used in order to prevent the separation between concrete core and steel tube due to shrinkage of encased concrete. Compressive strength determined from the expansive concrete cylinders cured in moulds, $F_{c}{ }^{\prime}$, is shown in Table 1 , and it is an average of three measurements. Stress-strain relations for the concrete are plotted in Fig. 2.

Tubes were cold worked welded mild steel, and all tubes were annealed to remove the residual stresses in the cross section. The material is the structural steel called STKR 41 in Japanese Industrial Standard. The actual dimensions are listed in Table 3. Material properties of steel tubes were determined from tensile coupon tests. Three coupons were taken from each steel tube, and those were cut out from plates which did not include welded seam. Typical stress-strain curve is shown in Fig. 3 . The relevan tvalues pertaining to the elastic, yield and strain-hardening ranges of the steel, as defined in Fig. 3, are listed in Table 3.

Experimental apparatus : A test set-up of columns subjected to axial load and bending moment is shown in Fig. 4. The axial load was transferred to the specimen through two parallel knife-edge supports (A) to allow for complete freedom of rotation of the specimen in the plane of the applied bending moment. Spherical ball bearing supports were used for the specimens of Series I instead of knife-edge supports. The end details were such that the steel and concrete were loaded together at the ends. Two hydraulic jacks (B), connected to the same pressure source, were used to exert upward loads througn $10 \mathrm{t}$ load cells. The tie rod arrangements $(\mathrm{C})$ were designed to allow for unrestrained

Table 3 Actual dimensions and mechanical properties of steel tubes used in tests

\begin{tabular}{|c|c|c|c|c|c|c|c|c|c|c|c|}
\hline & $\begin{array}{c}D \\
(\mathrm{~cm})\end{array}$ & $\begin{array}{c}t \\
(\mathrm{~mm})\end{array}$ & $D / t$ & $\begin{array}{c}{ }_{s} A \\
\left(\mathrm{~cm}^{2}\right)\end{array}$ & $\begin{array}{c}s^{\sigma} y \\
\left(t / \mathrm{cm}^{2}\right)\end{array}$ & $\begin{array}{c}\sigma_{u} \\
\left(\mathrm{t} / \mathrm{cm}^{2}\right)\end{array}$ & $s^{\sigma} \sigma_{y} / \sigma_{u}$ & $\begin{array}{c}\varepsilon_{f} \\
(\%)\end{array}$ & $\varepsilon_{s t} / \varepsilon_{y}$ & $E_{s t} / E$ & $\begin{array}{c}E \\
\left(10^{9} \mathrm{t} / \mathrm{cm}^{2}\right)\end{array}$ \\
\hline $2-1$ & 10.0 & 2.29 & 44 & 8.78 & $1.98^{*}$ & 3.53 & 0.56 & 30 & 21 & 0.014 & 2.10 \\
\hline $2-2$ & 10.0 & 2.27 & 44 & 8.75 & 3.11 & 3.98 & 0.78 & 27 & 17 & 0.006 & 2.13 \\
\hline $2-3$ & 10.0 & 2.20 & 45 & 8.43 & 3.46 & 4.19 & 0.83 & 25 & 18 & 0.007 & 2.18 \\
\hline $2-4$ & 10.0 & 2.22 & 45 & 8.55 & 2.95 & $3: 86$ & 0.77 & 29 & 18 & 0.007 & 2.20 \\
\hline $3-1$ & 10.0 & 2.98 & 34 & 11.31 & 2.95 & 4.09 & 0.72 & 25. & 12 & 0.010 & 2.15 \\
\hline $3-2$ & 10.0 & 2.99 & 33 & 11.35 & 2.94 & 4.12 & 0.71 & 29 & 13 & 0.011 & 2.10 \\
\hline $3-3$ & 10.0 & 2.99 & 33 & 11.35 & 2.94 & 4.12 & 0.71 & 29 & 13 & 0.011 & 2.10 \\
\hline $4-1$ & 10.0 & 4.25 & 24 & 15.85 & 2.90 & 4.00 & 0.72 & 29 & 14 & 0.011 & 2.30 \\
\hline $4-2$ & 10.0 & 4.25 & $\cdots \cdot 24$ & 15.85 & 2.91 & 4.01 & 0.73 & $\cdots-29-\cdots$ & $\cdots 13$ & $-\theta .010$ & 2.30 \\
\hline $4-3$ & 10.0 & 4.26 & 23 & 15.88 & 2.94 & 4.05 & 0.73 & 28 & 13 & 0.010 & 2.20 \\
\hline
\end{tabular}

* Tube 2-1 was annealed in atmosphere at $740^{\circ} \mathrm{C}$, and all other tubes were annealed in atmosphere at $650^{\circ} \mathrm{C}$.

Note : $D=$ breadth and depth of steel tube. ${ }_{s} \sigma_{y}=$ yield point stress. $\sigma_{u}=$ tensile strength. ${ }_{s} A=$ cross sectional area. $\varepsilon_{y}=$ strain at first yield. $\varepsilon_{f}=$ maximum elongation. $t=$ thickness of wall. $\varepsilon_{s t}=$ strain at start of strain hardening. $E=$ modulus of elasticity. $E_{s t}=$ strain hardening modulus.

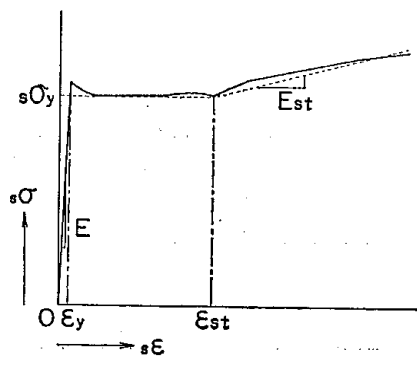

Fig. 3 Stress strain curve for steel
(A) Knife-edge support (C) Tie rod arrangement

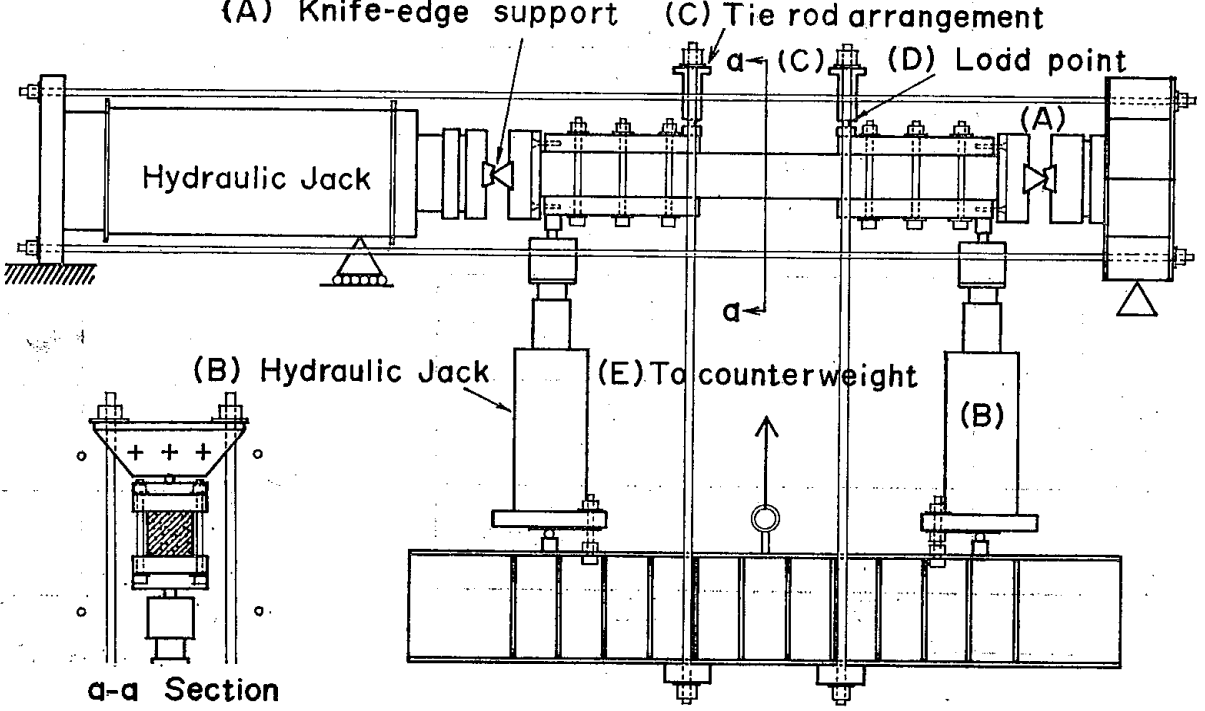

Fig. 4 Test set-up 
rotation of the specimen at load points (D). The weight of the bending moment arrangement was taken off by a counterweight (E).

Rotation of test region was determined by the use of rotation meters consisting of two frames clamped to transverse sections $20 \mathrm{~cm}$ apart (see Figs. 1 and 5). Dial gauges reading to $0.01 \mathrm{~mm}$ were fitted to the top and bottom of the frames in order to measure displacements due to relative rotation of the sections. Three electrical deflection gauges $10 \mathrm{~cm}$ apart were used

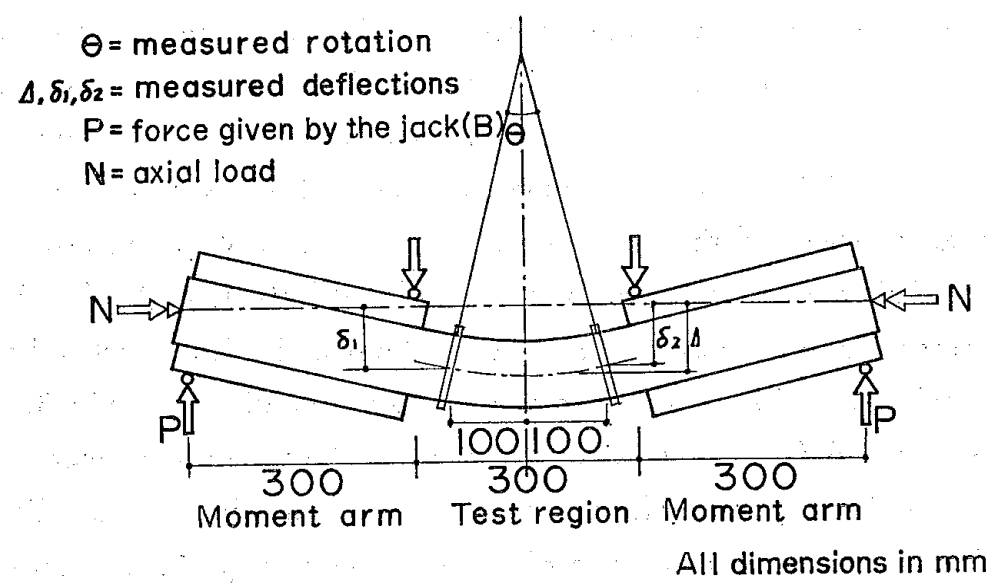

Fig. 5 Bent specimen during test to measure the deflections along the test region at three points shown in Fig. 5. The layout of the strain gauges is shown in Fig. 1.

Columns subjected only to axial load were concentrically loaded through spherical ball bearing seats.

Experimental procedure : After the constant axial load was applied, a monotonic increasing moment was applied to the specimen by increasing the pressure in jacks (B). As a result of the deflections of the bent specimens during tests, the actual moment at midheight of specimens was the sum of the moment applied by the jacks (B) and the additional moment ( $N-4$ moment) due to the axial load and deflection.

The rotation, deflections and strains were recorded between load applications. The deflections were held constant during this time. This resulted in a decrease of bending moment due to creep but, since the readings were performed relatively quickly, the creep effects on the measurements were probably unimportant. Local bucklings of the steel tube were marked as they were observed by the naked eye. A complete test took on an average about 45 to 60 min. utes

\section{EXPERIMENTAL RESULTS}

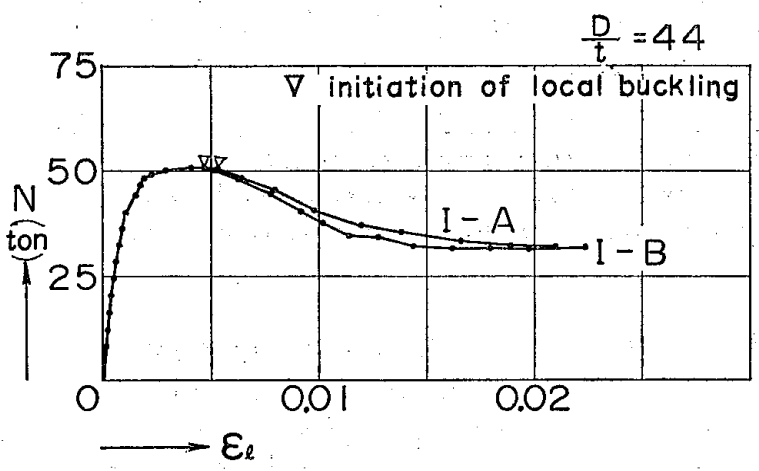

(a)

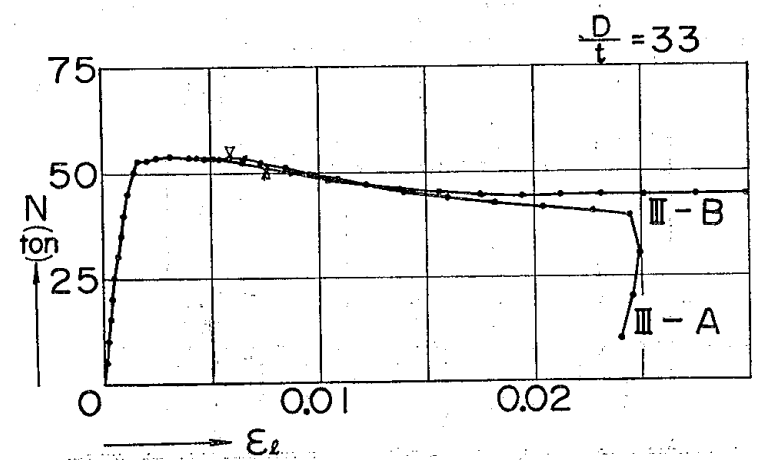

(c)

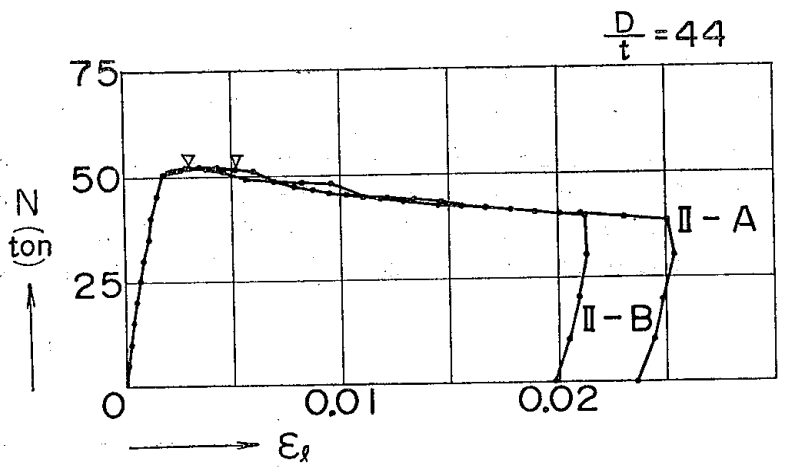

(b)

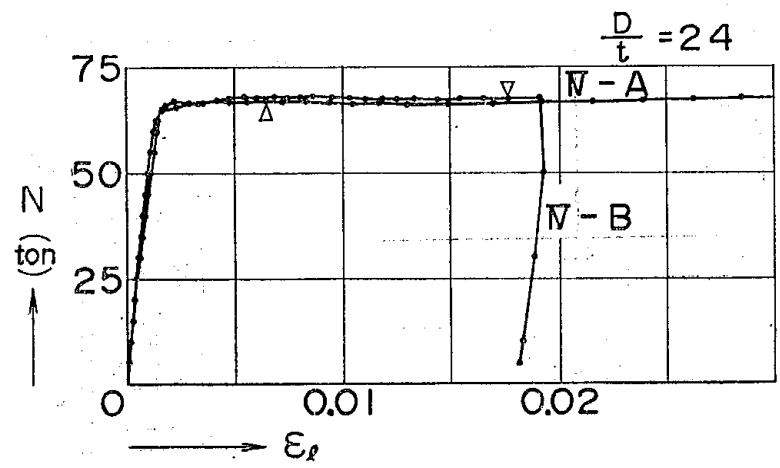

(d)

Fig. 6 Axial load-average longitudinal strain relationships for all specimens 
Concentrically loaded columns : Relationships between axial load and average longitudinal strain for concentrically loaded columns are shown in Fig. 6, and the ultimate loads are shown in Table 1. The ultimate loads are slightly larger than calculated values $N_{0}{ }^{\prime}{ }_{s} A{ }_{s} \sigma_{y}+{ }_{c} A F_{c}{ }^{\prime}$ (see Table 1 ). It is considered that one reason for this is that compressive strength of concrete cores cured in steel tubes may have differed from that of concrete cylinders cured in moulds.

Tomii, Yoshimura and Morishita investigated experimentally the compressive strength of concrete cores cured in circular steel tubes and concrete cylinders cured in moulds both for concrete without ex-

TY: yield point of tension side of steel tube

$C Y$ : yield point of compression side of steel tube

$\nabla$ : initiation of local buckling of flange

$\$$ : initiation of local buckling of web

$\nabla$ : ultimate moment

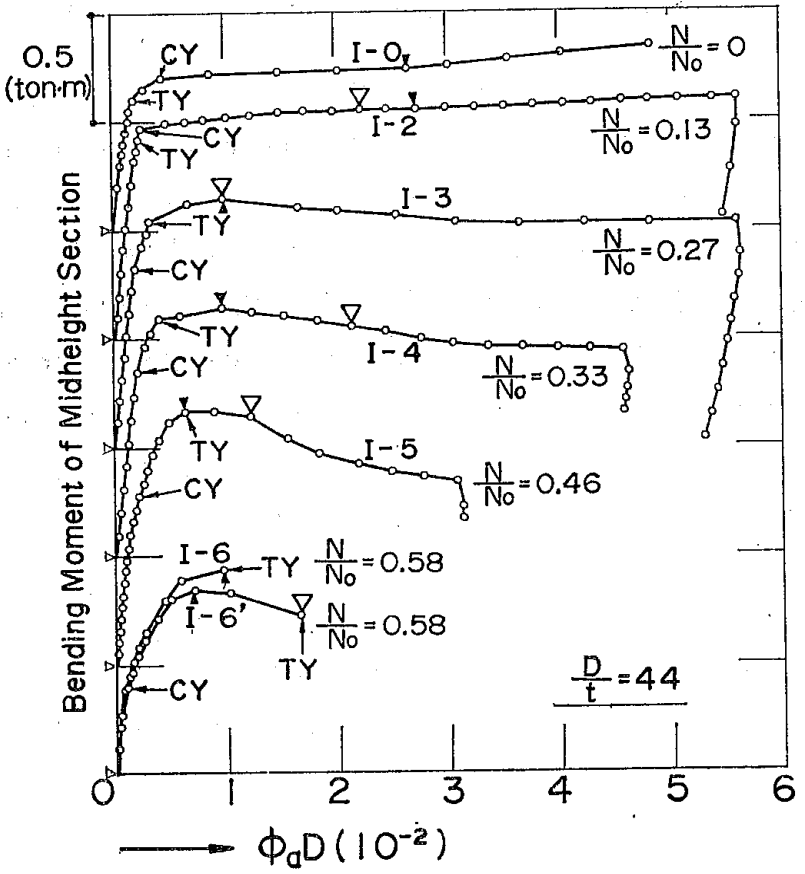

(a)

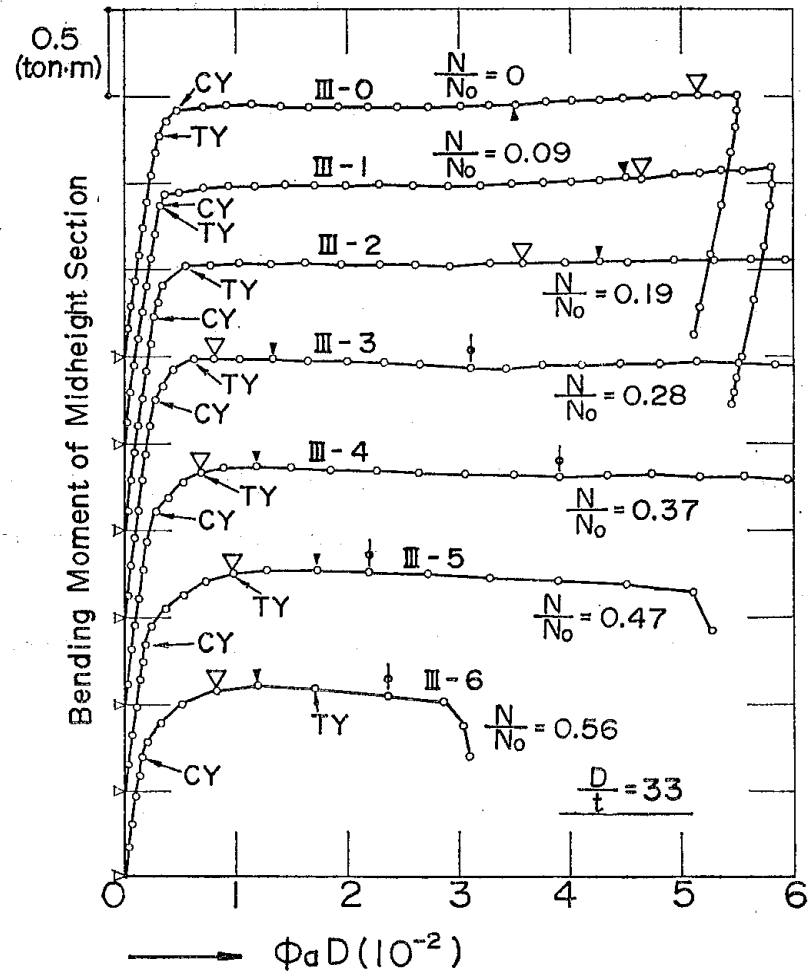

(c)

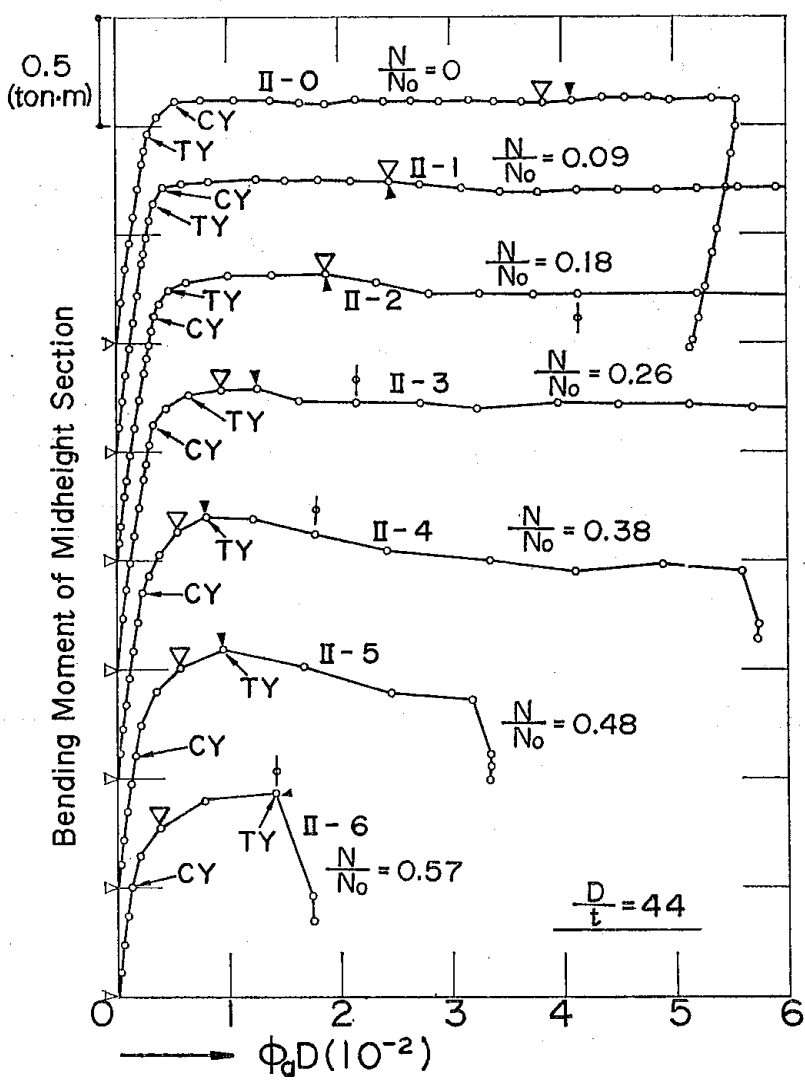

(b)

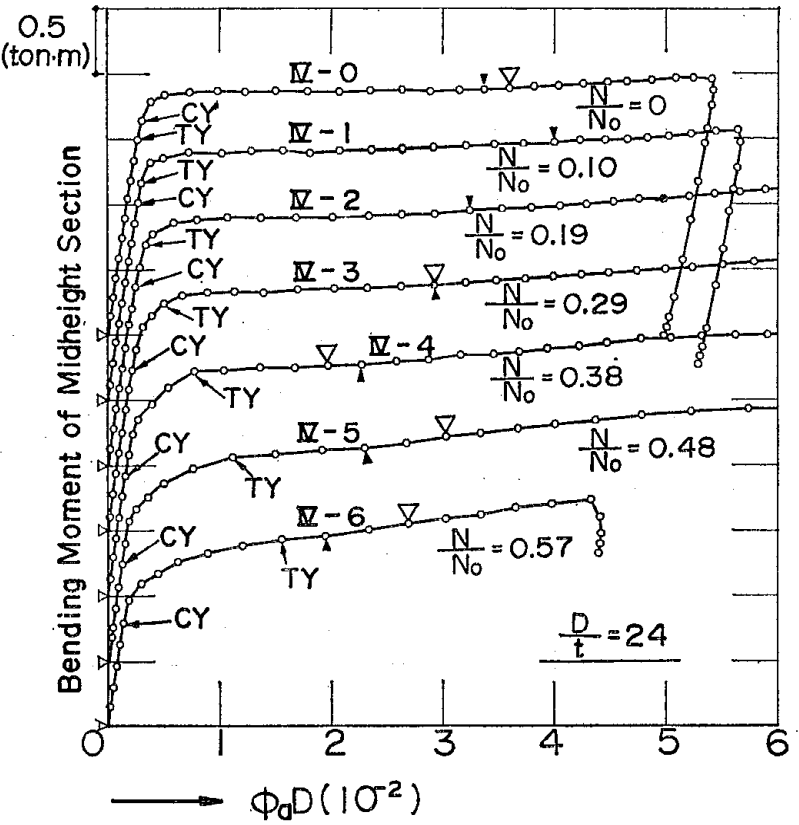

(d)

Fig. 7 Experimental moment-thrust-curvature relationships for all specimens 
pansive component (referred to as normal concrete) and for concrete made with cement containing 15 percent of expansive component. They reported that for normal concrete the compressive strength of concrete core, ${ }_{c} \sigma_{B}$, was approximately the same as that of concrete cylinder, $F_{c}$, while for expansive concrete ${ }_{c} \sigma_{B}$ was about 1.2 times the compressive strength of concrete cylinder, $F_{c}{ }^{(5)}$ (see Table 4).

If $c^{\sigma_{B}}$ is assumed to be 1.2 times $F_{c}{ }^{\prime}$, ultimate loads of concentrically loaded columns are approximately the same as nominal squash loads

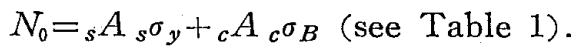

Table $4 *$ Comparison between the compressive strength of concrete cores cured in circular steel tubes, $c^{\sigma_{B}}$, and the compressive strength of concrete cylinders cured in moulds, $F_{c}$ or $F_{c}{ }^{\prime}$

\begin{tabular}{c|c|c|c|c}
\hline \multirow{2}{*}{ Concrete } & \multicolumn{3}{|c|}{$c^{\sigma_{B}\left(\mathrm{~kg} / \mathrm{cm}^{2}\right)}$} & $F_{c}$ or $F_{c}{ }^{\prime}$ \\
& $t=3 \mathrm{~mm}$ & $t=4 \mathrm{~mm}$ & $t=5.5 \mathrm{~mm}$ & $\left(\mathrm{~kg} / \mathrm{cm}^{2}\right)$ \\
\hline \multirow{2}{*}{ Normal } & 365 & 380 & 375 & 359 \\
concrete & 262 & 256 & 264 & 260 \\
& 170 & 174 & 173 & 172 \\
\hline \multirow{2}{*}{ Expansive } & 367 & 368 & 361 & 286 \\
concrete & 257 & 255 & 256 & 201 \\
& 160 & 159 & 159 & 140 \\
\hline
\end{tabular}

* These results are reported in Ref. 5 .

Note : Each value of compressive strength is an average of three measurements. $t=$ thickness of circular steel tube wall. Outside dimension of steel tube is $10 \mathrm{~cm}$.

Columns subjected to axial load and bending moment: The moment-thrust-curvature relationships (referred to as $M-N-\phi$ relationships) are shown in Fig. 7, and ultimate moments are given in Table 1. In Fig. 7, bending moment of midheight section includes $N-\Delta$ moment, and $\phi_{a}$ is an average curvature which is given by the rotation readings. Strain readings also give the curvature of three sections, $\phi_{w_{1}}, \phi_{w 2}, \phi_{w 3}$ (see Fig. 1). For small values, $\phi_{w_{1}}, \phi_{w_{2}}, \phi_{w_{3}}$ and $\phi_{a}$ show close agreement, but in some tests for higher values they differ appreciably. The $\phi_{w_{1}}, \phi_{w_{2}}, \phi_{w_{3}}$ values are not available at high curvature because the local buckling of steel tube wall occures. Therefore, $\phi_{a}$ is used in all the $M-N-\phi$ plots. In Fig. 7, the axial load is given in the nondimensional form $N / N_{0}$ where $N_{0}$ is the nominal squash load. As can be seen from Fig. 7, the value of $N / N_{0}$ and the external wall breadth to wall thickness ratio, $D / t$, have a significant effect on the $M-N-\phi$ relationships. The $M-N-\phi$ relationships of columns $\mathrm{I}-5, \mathrm{I}-6, \mathrm{I}-6^{\prime}, \mathrm{II}-5, \mathrm{II}-6$, whose $N / N_{0}$ and $D / t$ are large, are rather brittle. However, it should be noted that even in those columns tension side of the steel tube yielded in tension.

\section{ULTIMATE MOMENT}

The ultimate moment for given axial load can be estimated by the computation procedure for the $M-N-\phi$ relationships. However, this procedure is complicated to calculate. ... Furlong concluded that accurate estimates of beam-column strength were made by treating the concrete filled tubes as ordinary reinforced concrete sections, and recommended to use the capacity rules of A.C.I. Building Code, but in his paper the intensity of concrete stress was taken as $F_{c}$ instead of $0.85 F_{c}$ recommended by A.C.I. (referred to as modified A.C.I. method). However, the calculation of this procedure is also complicated, because the stress distribution of steel tube web is much more complicated than ordinary reinforced concrete. In this section a simpler estimation method which is able to predict the ultimate moment is proposed.

Proposed method : The stress blocks shown in Fig. 8 are assumed for steel tube and concrete core in the proposed method. The value of concrete stress $c^{\sigma_{B}}$ is taken as $F_{c}$ as recommended by Furlong. However, $c^{\sigma_{B}}$ is taken as $1.2 F_{c}{ }^{\prime}$ in the calculations for specimens for which expansive concrete is used for the same reason described in the preceding section.

From the equilibrium of axial direction, depth of the neutral axis, $x_{n}$, at ultimate moment for given axial load is given by Eq. 1 :

where

$$
x_{n i}=\left\{\frac{2 t_{1} s^{\sigma_{y}}+\left(1-2 t_{1}\right) t_{1} c^{\sigma_{B}}+\frac{N}{D^{2}}}{\left(1-2 t_{1}\right)_{c} \sigma_{B}+4 t_{1} \sigma_{y}}\right\} D \quad \text { for } \quad\left(t \leqq x_{n} \leqq D-t\right)
$$

$$
\begin{aligned}
& t_{1}=t / D, \\
& N=\text { axial load. }
\end{aligned}
$$

Ultimate moment, $M_{u}$, for given axial load is given by Eq. 2 : 

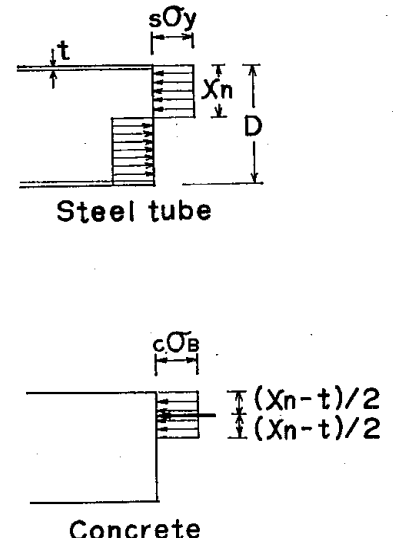

Fig. 8 Assumed stress blocks of steel tube and concrete

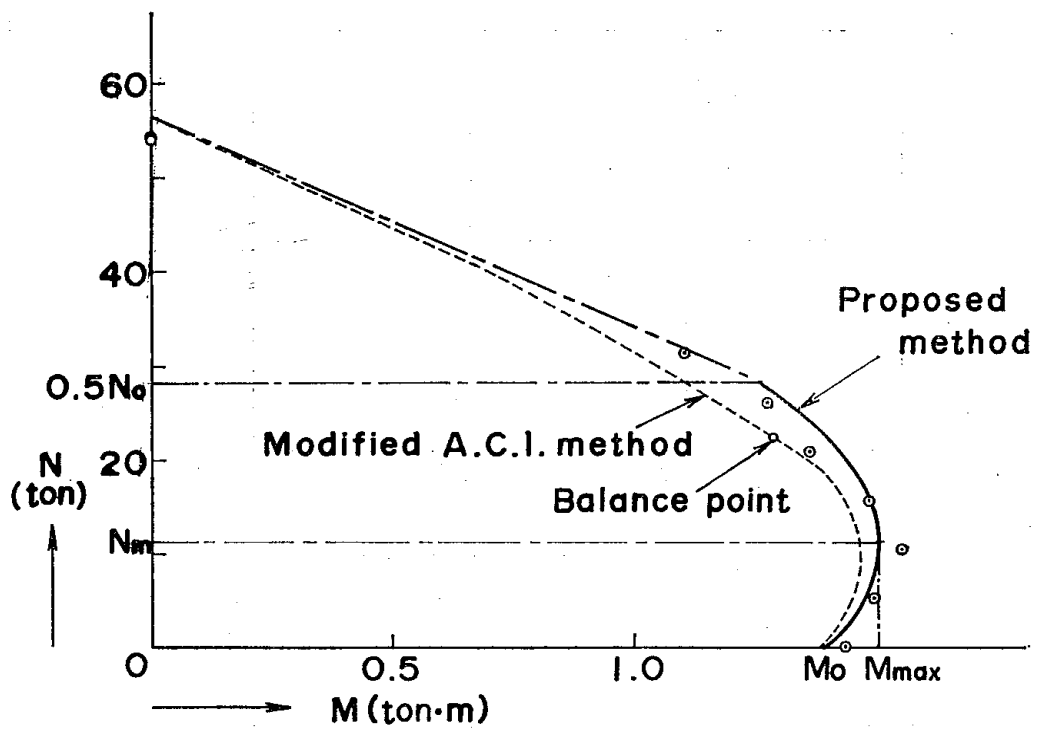

Fig. 9 Axial load-ultimate moment interaction curves for series III

$$
M_{u}=\left\{t_{1}\left(1-t_{1}\right)_{s} \sigma_{y}+2\left(x_{n 1}-t_{1}\right)\left(1-x_{n 1}-t_{1}\right) t_{1} \sigma_{y}+0.5\left(1-2 t_{1}\right)\left(1-x_{n 1}-t_{1}\right)\left(x_{n 1}-t_{1}\right)_{c^{\sigma}}\right\} D^{3},
$$

where

$$
x_{n 1}=x_{n} / D \text {. }
$$

The interaction curve between axial load and ultimate moment (referred to as $N-M$ interaction curve) derived from the proposed method is shown in a solid line in Fig. 9. Also in Fig. 9, data points for the test specimens of Series III are shown with circled dots, and the result by modified A.C.I. method is shown in a dashed line. By the proposed method, ultimate moment for the case of zero axial load, $M_{0}$, maximum ultimate moment in the $N-M$ interaction curves, $\mathrm{M}_{\mathrm{max}}$, and axial load corresponding to $M_{\max }, N_{m}$, are given by Eqs. 3,4 and 5 :

$$
\begin{aligned}
& M_{0}=\left\{1+\frac{(1-\alpha)\left(1-4 t_{1}\right)}{3\left(1-4 t_{1}+2 t_{1} \alpha\right)}\right\} M_{p} \doteqdot\left\{1+\frac{1-\alpha}{3}\right\} M_{p}, \\
& M_{\max }=M_{p}+{ }_{c} M_{\max }=\frac{D^{3}}{4} s^{\sigma}\left\{1-\left(1-2 t_{1}\right)^{3}\right\}+\frac{D^{3}}{8} c^{\sigma_{B}}\left(1-2 t_{1}\right)^{3}, \\
& N_{m}=\frac{{ }^{A}{ }_{c} \sigma_{B}}{2}
\end{aligned}
$$

where

$$
\alpha=\frac{{ }_{s} N_{0}}{N_{0}}=\frac{{ }_{s} A{ }_{s} \sigma_{y}}{{ }_{s} A{ }_{s}{ }{ }_{y}+{ }_{c} A_{c_{c}{ }_{B}}}
$$

$M_{p}=$ full plastic moment capacity of steel tube,

${ }_{c} M_{\mathrm{max}}=$ maximum moment capacity of concrete core.

The ratio $M_{u} / M_{\text {cal }}$ against $N / N_{0}$, where $M_{u}$ is experimental ultimate moment of our test or Furlong's test ${ }^{1)}$ and $M_{\text {cal }}$ is theoretical ultimate moment given by the proposed method or modified A.C.I. method, is mentioned in Figs. $10 \mathrm{a}, 10 \mathrm{~b}, 11 \mathrm{a}$ and $11 \mathrm{~b}$. Here, experimental ultimate moments of the specimens of Series IV were defined as the moments of flat plateaus of their $M-N-\phi$ curves (see Fig. 7). The values of ratio $M_{u} / M_{\text {cal }}$ for Furlong's experimental results are scattered as shown in Fig. $10 \mathrm{~b}$. It is considered that this scattering is due to the properties of steel tubes which are not annealed.

The proposed method introduces a great simplification of calculation, but it cannot predict the balance point where the tension side of steel tube just reaches its yield point when the ultimate moment is attained. For the column subjected to high axial load greater than the axial load corresponding to balance point, $N_{b}$, the tension side of steel tube never reaches its yield point. In that case, the assumed stress block for steel tube is not valid.

As shown in Fig. $10 \mathrm{a}$, the calculated ultimate moments given by the proposed method are overestimated for the two columns of Series $I, I-6$ and $I-6^{\prime}$, which were tested under high axial load 


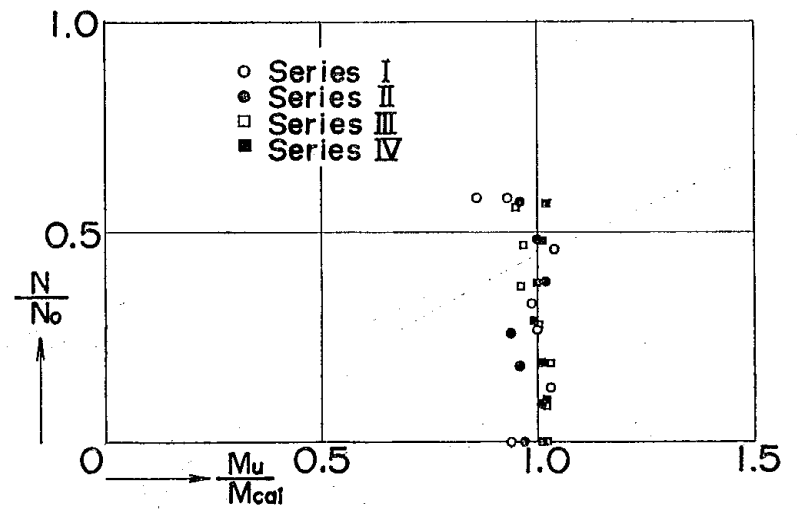

(a) The comparison using our experimental results

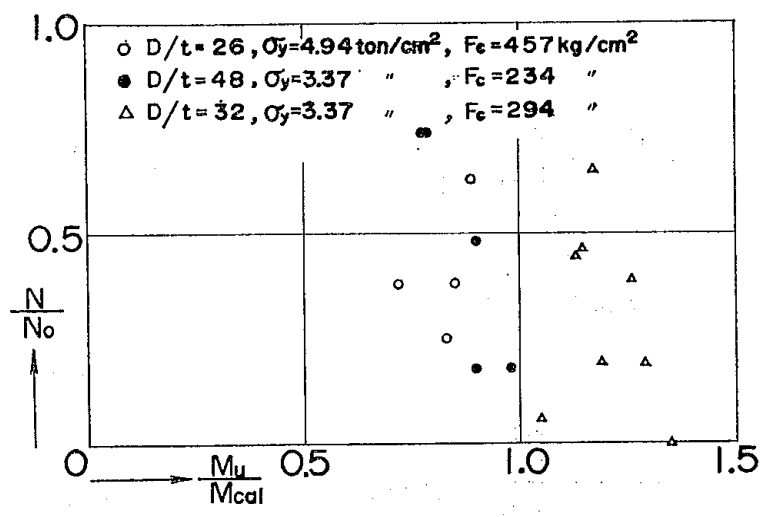

(b) The comparison using Furlong's experimental results

Fig. 10 Comparison between experimental ultimate moments, $M_{u}$, and theoretical ones, $M_{\mathrm{cal}}$, giuen by our proposed method

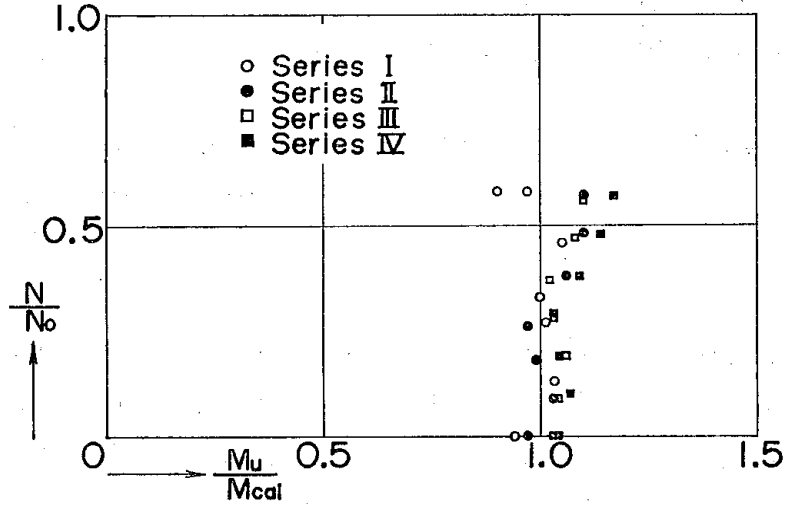

(a) The comparison using our experimental resuslts

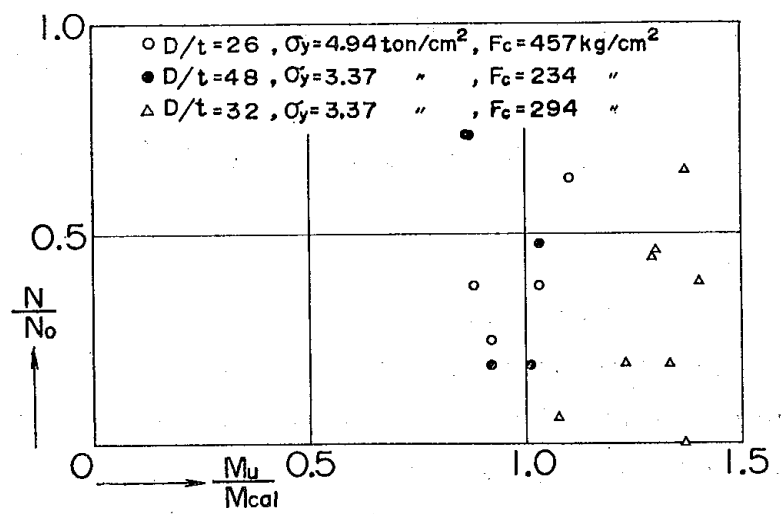

(b) The comparison using Fulong's experimental results

Fig. 11 Comparison between experimental ultimate moments, $M_{u}$, and theoretical ones, $M_{\text {cal }}$, given by modified A.C.I. method proposed by Prof. R.W. Furlong

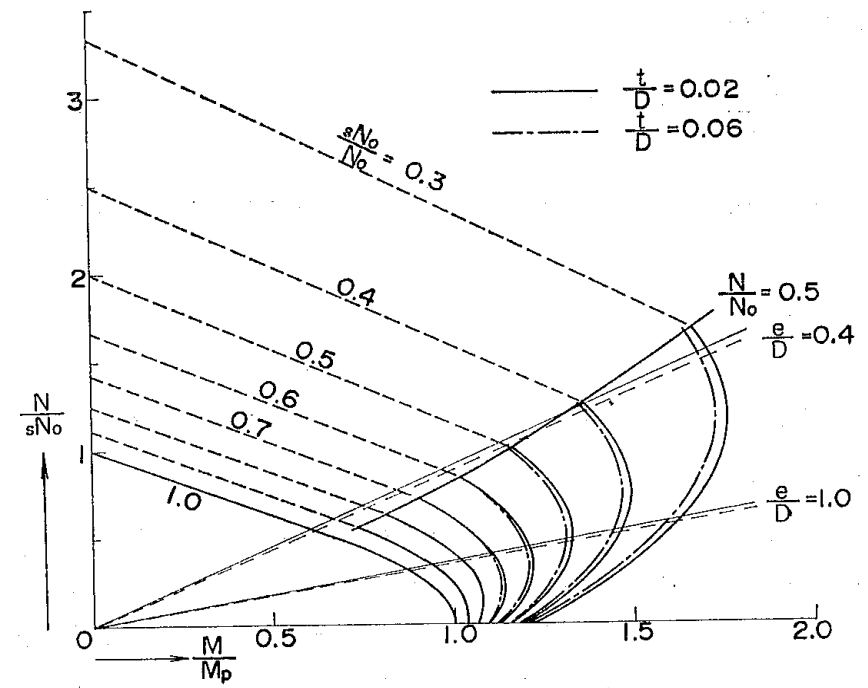

Fig. 12 Nondimensional interaction curves

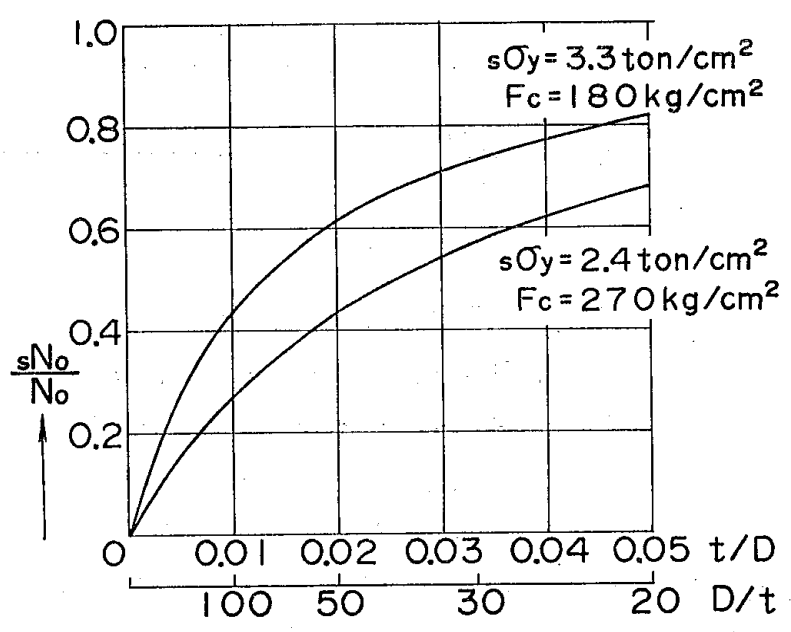

Fig. $13{ }_{s} N_{0} / N_{0}-D / t$ (or $t / D$ ) relationships $\left(N / N_{0}=0.58\right)$.

Furthermore, validity of the proposed method for the columns subjected to $N / N_{0}$ greater than 0.58 cannot be confirmed by our experiment in which $N / N_{0}$ of the columns was taken as $0 \sim 0.58$.

From the above consideration, the proposed method is applicable to the columns subjected to the $N$ which is less than $0.5 N_{0}$.

Design charts : The nondimensional interaction curves derived from the proposed method are shown in Fig. 12 for various values of the parameter ${ }_{s} N_{0} / N_{0}$. - In Fig. 12, ${ }_{s} N_{0}$ is the squash load of steel tube, $M_{p}$ is the full plastic moment capacity of steel tube, and $e$-is the eccentricity of the axial load 
$N$ from the centroid of the column. Columns with different values of the steel tube wall thickness have 'slightly different nondimensional interaction curves, though they have the same value of parameter ${ }_{s} N_{0} / N_{0}$. This is due to the difference of nondimensional section size, $(D-2 t) / D$, of concrete core.

Fig. 13 shows the relations between ${ }_{s} N_{0} / N_{0}$ and $D / t$ (or $t / D$ ). In our experiment, the value of ${ }_{s} N_{0} / N_{0}$ was taken as 0.31 $\sim 0.70$.

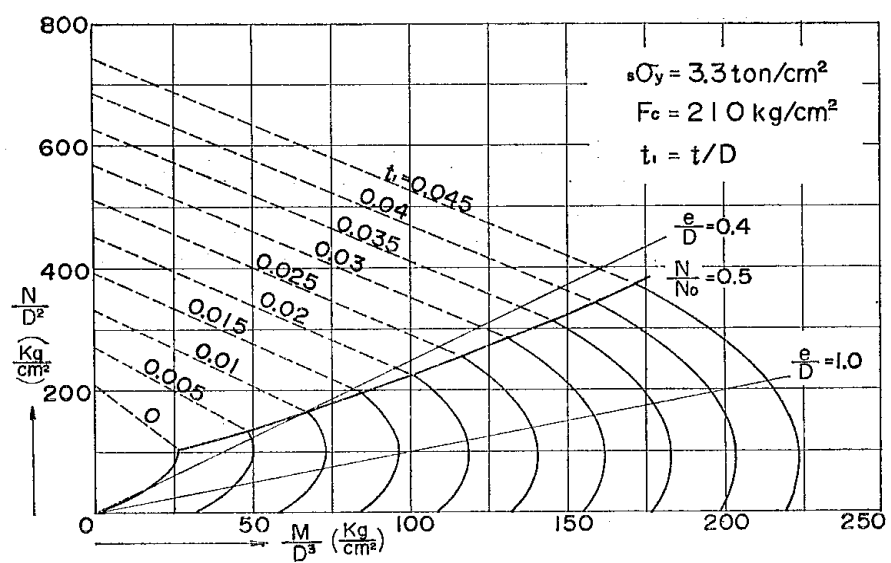

Fig. 14 Interaction charts for given columns

The most convenient form for a design chart for columns is obtained by plotting $N / D^{2}$ against $M /$ $D^{3}$ for various of the parameter $t / D$, and by assuming material properties to be constant for a particular chart. Fig. 14 is a sample of design chart for ultimate strength design.

\section{CONCLUSIONS}

The following conclusions are reached on bases of the study which has been presented.

(1) The magnitude of constant axial load and wall breadth to wall thickness ratio, $D / t$, of steel tube had a significant effect on an inelastic behavior of the concrete filled square steel tubular columns subjected to axial loads and bending moments, especially on the falling branch of the moment-thrust-curvature relationships. The moment-thrust-curvature relationships of the columns having a $D / t$ ratio of $24 \mathrm{did}$ not have any falling branch. However, the columns having a $D / t$ ratio of 44 were rather brittle when they were subjected to high axial load and moment (see Fig. 7).

(2) The ultimate moment which is an important quantity for structural design can be estimated accurately by the proposed simple method for the columns in which annealed steel tubes are used (see Fig. 10 a). This proposed method is applicable for the columns subjected to the axial load $N$ which is less than $0.5 N_{0}\left(N_{0}={ }_{s} A_{s} \sigma_{y}+{ }_{c} A_{c} \sigma_{B}\right)$. It is considered that this limitation of $N / N_{0}$ does not cause inconvenience to actual design.

The numerical simulation of the moment-thrust-curvature characteristics will be reported in Transactions of the Architectural Institute of Japan in the near future.

\section{ACKNOWLEDGEMENTS}

This investigation was carried out at Kyushu University, and was made possible by the financial support from Grant in Aid for Scientific Research of Ministry of Education.

The authors wish to thank Messrs. K. Kiyohara, H. Ishibashi and H. Kanegae of Kyushu University for their assistance in this experiment.

\section{REFERENCES}

1. Furlong, R.W., "Strength of Steel-Encased Concrete Beam Columns", Journal of the Structural Division, ASCE, Vol. 93, No. ST 5, Oct., 1967.

2. Knowles, R.B. and Park, R., "Strength of Concrete Filled Steel Tubular Columns", Journal of the Structural Division, ASCE, Vol. 95, No. ST 12, Dec., 1969.

3. Sen, H.K., "Triaxial Effects in Concrete-Filled Tubular Steel Columns", PhD. Thesis, University of London, 1969.

4. Yamada, M., Sakae, K. and Kondoh, K., "Elasto-Plastic Flexural Deformation of Concrete Filled Steel Tube Beam-Columns", Transactions of the Architectural Institute of Japan, No. 233, July, 1975. (in Japanese)

5. Tomii, M., Yoshimura, K., Morishita, Y., Fukihara, M. and Shibuya, O., "Experimental Studies on Bond Stress between Steel Tube and Concrete Core of Concrete Filled Circular Steel Tubular Columns", Reports of Chugoku-Kyushu-Chapter of the Architectural Institute of Japan, No. 4, Feb., 1978. (in Japanese) 


\section{軸カと曲げを受けるコンクリート充填角形鋼管柱の 曲げ終局強度に関する実験的研究（梗概）}

$\begin{array}{lllll}\text { 正会員 } & \text { 富 } & \text { 井 } & \text { 政 } & \text { 英* } \\ \text { 正会員 } & \text { 崎 } & \text { 野 } & \text { 健 } & \text { 治** }\end{array}$

\section{1. 序}

鋼管は中空あるいはコンクリート充てん鋼管部材とし て構造部材に使用されることが多くなってきた。

コンクリート充てん鋼管柱は，せん断破壊よりも曲げ 破壊が先行する場合が多く，曲げに対する性状を明らか にすることは, 構造設計上重要な研究課題となってい る。

軸力と曲げを受けるコンクリート充てん鋼管柱に関し ては, 円形断面柱については, Furlong ${ }^{1)}$, Knowles 等 ${ }^{2\rangle}$, $\mathrm{Sen}^{3 \mathrm{3}}$ ，山田等 ${ }^{4)}$ の研究があるが，正方形断面柱に関して は研究が少ない。一定軸力と曲げを受けるコンクリート 充てん正方形断面鋼管柱 (以下コンクリート充てん角形 鋼管柱と書く) に関する実験的研究として Furlong の 研究吕があるが，これは主として曲げ終局強度に注目し たものであり，変形性状（曲げモーメント・曲率関係）

については述べられていない。

本論文の目的は, 軸力と曲げを受けるコンクリート充 てん角形鋼管柱の曲げモーメント・曲率関係を実験的に 明らかにするとともに, 曲げ終局強度を簡単にかつ精度 よく求める方法を提案することである。

\section{2. 実験計画}

試験体 : $10 \mathrm{~cm} \times 10 \mathrm{~cm}$ の断面を持つ計 36 体の試験体 について, シリーズ I から IV までの 4 シリーズの実験 を行なった。それぞれのシリーズは，中心圧縮柱が 2 体 と, 軸力と曲げを受ける柱が 7 体の計 9 体からなる（表 1 参照)。各シリーズ間の実験変数注鋼管板厚と材料強 度である。また，同一シリーズ内での実験変数は，一定 軸力の大きさである。試験体の形状を図 1 亿示す。

シリーズエを除き，同一シリーズの試験体に注同一バ ッチのコンクリートを使用した。試験体製作と同時に $10 \mathrm{~cm} \times 20 \mathrm{~cm}$ のシリンダーを製作した。試験体の両端 部恃キッピングをし，鋼管とコンクリートが同一面と なるよらにした。試験体とシリンダーは室内養生をし た。シリンダーは型枠に大れたまま養生を行なった。 材料：コンクリートの重量調合比を表 2 に示す。な

* 九州大学 教授・工博

** 九州大学 助手・工修

(昭和 53 年 1 月 31 日本稿受理・討論期限昭和 54 年 4 月末日)
お，コンクリートの収縮による鋼管と充てんコンクリー トのはだ離れを防ぐために，膨張材をセメント内割で 15\% 混入した膨張セメントを使用した。型枠養生した 膨張コンクリートシリンダーの圧縮強度 $F_{c}{ }^{\prime}$ を表 1 に, 応力度・ひずみ度関係を図 2 に示す。

鋼管は冷閒加工の電縫鋼管を焼鈍して使用した。焼針 前の材質は STKR 41 である。引張試験より求めた焼鈍 後の鋼管の力学的性質と奏測寸法を表 3 亿, 応力度・ひ ずみ度関係の 1 例を図 3 に示す。

実験装置 : 軸力と曲げを受ける柱の加力装置を図 4 に 示す。軸力加力部の拘束をなくすために，2 組のナイフ エッジ（A）を用いた。ただし，シリーズＩの実験には 球座を使用した。試験体画端面に扮いては，鋼管とコン クリートを同時に圧縮 した。2 台の油圧ジャッキ（B) は連動して用い，ロードセルにより力を計測した。加力 点（D）に抒いては，拘束をなくすため, 球をそら入し ている。曲げモーメント載荷装置は, 自重を取り除くた め,カウンターウエイトにより吊り上げた。

$20 \mathrm{~cm}$ 閒隔に取り付けた測定フレーム上下にダイアル ゲージを取り付け, 試験体部分の回転角の測定を行なっ た (図 1,5 参照)。図 5 に示す 3 点で, 試験部分のた わみを変位計により電気的に測定した。

中心圧縮柱は 2 組の球座を用いて加力を行なった。

実験方法：一定軸力を加力した後曲げモーメントを加 カした。鋼管の局部座屈の観測は肉眼によった。 一体の実験に要した時間は 45〜60 分であった。

\section{3. 実 験 結 果}

中心圧縮柱 : 軸力 $N$ と平均軸方向ひずみ度 $\varepsilon_{l}$ との関 係を図 6 に示し，中心圧縮耐力の值を表 1 亿示す。中心

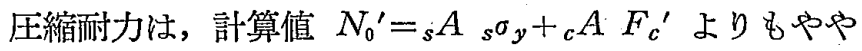
大きい (表 1 参照)。この原因として, シリンダーと充 てんコンクリートの圧縮強度の違いが考㝋られる。

富井, 吉村, 森下らは, 円形鋼管中で養生したコンク リートと型枠中で養生したシリンダーの圧縮強度の比較 実験を行ない，普通コンクリートの場合注両者の压縮強 度はほぼ同じであるが，膨張材をセメント内割で $15 \%$ 混入した膨張コンクリートの場合は鋼管中で養生したコ ンクリートの圧縮強度 $c^{\sigma} B$ 注型枠養生したシリンダー強 
度 $F_{c}^{\prime}$ の約 1.2 倍であることを報告5)している（表 4 参照)。

充てルコンクリートの圧縮強度 $c^{\sigma}{ }_{B}$ を $1.2 F_{c}{ }^{\prime}$ と考 えると, 中心圧縮耐力は単純累加中心圧縮耐力

$$
N_{0}={ }_{s} A{ }_{s^{\sigma}}{ }_{y}+{ }_{c} A{ }_{c} \sigma_{B}
$$

とほぼ等しい (表 1 参照)。

軸力と曲げを受ける柱 : 曲げモーメントと軸力と曲率 の関係 (以下 $M-N-\phi$ 関係と書く) を図 7 に示し, 曲 げ終局強度の值を表 1 亿示す。図 7 にお゙いて, 縦軸は軸 力による付加曲げモーメントを含んだ試験部分中央断面 の曲げモーメントであり， $\phi_{a}$ は回転角の測定より得ら れた試験部分の平均曲率である。図 7 から, 軸力比 $N /$ $N_{0}$ と鋼管の幅と板厚 の比 $D / t$ は $M-N-\phi$ 関係に大き な影響を及ぼすことがわかる。 $N / N_{0}$ と $D / t$ が大きな試 験体（I-5，I-6，I-6'，II-5，II-6） はむし万脆性的 な挙動を示した。しかしながら,これらの試験体におい ても，鋼管の引張縁は引張降伏を起こしていた。

\section{4. 曲げ終局強度}

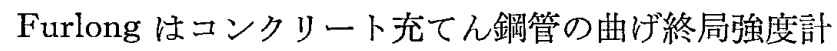
算法として, A.C.I. 規準の耐力計算法を準用することを 提案している1。すなわち，コンクリートの応力ブロッ クの高さを A.C.I. 規準の $0.85 F_{c}$ 加 $1.0 F_{c}$ に高め て使用することを提案している（この計算法を以下修正 A.C.I. 法と書く)。しかしながら，この計算法は鋼管ウ エブの応力分布が複雑になり，計算が煩雑である。

本節においては, より簡単に曲げ終局強度を計算出来 る方法を以下に提案する。

計算法：鋼管扔よび充てんコンクリートに対して，図 8 亿示す応力ブロックを仮定する。コンクリートの応力 ブロックの高さ $c^{\sigma} B$ は, Furlong の提案したように充て んコンクリートの圧縮強度 $F_{c}$ をとる。ただし, 膨張コ ンクリートを充てんした本実験の試験体に対しては, 前 に述べた理由から $c^{\sigma_{B}}=1.2 F_{c}^{\prime}$ として計算した。

軸方向の力の釣り合い条件より, 圧縮縁から中立軸ま での距離 $x_{n}$ は 1 式で与えられる。また, 与光られた軸 力に対する曲げ終局強度 $M_{u}$ は 2 式で与えられる。

本計算法により求まる軸力と曲げ終局強度の相関曲線 (以下 $N-M$ 相関曲線と書く) を図 9 に実線で示す。ま た, 図 9 にはシリーズIIIの実験結果を○で, 修正 A.C.I. 法による計算結果を点線で示している。

本計算法によると, 軸力零の場合の曲げ終局強度 $M_{0}$ と $N-M$ 相関曲線上の最大の曲げ終局強度 $M_{\max }$ 拉よ び $M_{\max }$ に対応する軸力 $N_{m}$ は $3,4,5$ 式で与えら れる。

曲げ終局強度に関する実験值と計算值の比較を図 10 $\mathrm{a}, 10 \mathrm{~b}, 11 \mathrm{a}, 11 \mathrm{~b}$ に示す。実験值 $M_{u}$ は本実験および Furlong の実験 ${ }^{1} に よ り$ 得られた実験結果であり, 計算
值 $M_{\mathrm{cal}}$ 注本計算法と修正 A.C.I. 法により得られたも のである。ただし，シリーズ IV の試験体の曲げ終局強 度は， $M-N-\phi$ 曲線が平らになるところの曲げモーメン 卜と定義した (図 7 参照)。

図 $10 \mathrm{~b}$ に示されるように, Furlong の実験結果に対 しては実験值と計算值の比はかなりバラついている。こ の原因として，鋼管を焼鈍せずに使用していることが考 えられる。

本計算法によると計算が簡単になるが，曲げ終局強度 に達すると同時に鋼管引張縁が降伏するときの釣り合い 軸力を求めることが出来ない。釣り合い軸力より大きな 軸力を受ける柱の鋼管引張縁は曲げ終局強度に降伏点に 達することがなく，そのよらな柱に対しては鋼管の応力 ブロックに対する仮定は妥当ではなくなる。四 $10 \mathrm{a}$ か らもわかるよらに, シリーズIの試験体で軸力比の大き な $\left(N / N_{0}=0.58\right)$ 試験体 I- $6, I-6^{\prime}$ に対しては計算值 は実験值よりも大きい。また, 本実験の軸力比 $N / N_{0}$ の 範囲は $0 \sim 0.58$ であり, 軸力比が 0.58 以上の柱につ いては本計算法の妥当性が実証されていない。

以上のことを考慮して, 本計算法の適用範囲は軸力比 が 0.5 以下の場合とする。

設計図表 : 本計算法により求めた無次元化相関曲線を 図 12 に示寸。 ${ }_{s} N_{0}$ は鋼管の中心圧縮而力, $M_{p}$ は鋼管 の全塑性モーメント， $e$ は偏心距離である。図 13 は ${ }_{s} N_{0} / N_{0}$ と $D / t$ (あるいは $t / D$ ) の関係を示したもので ある。また，本実験における ${ }_{s} N_{0} / N_{0}$ の範囲は $0.31 \sim$ 0.70 である。

柱の設計図表としては, 縌軸に $N / D^{2}$, 横軸に $M / D^{3}$ をとり，材料強度を一定， $t / D$ をパラメータとして書い た図表が便利である。図 14 に終局強度にもとづく設計 図表の一例を示す。

\section{5. 結論}

本論により下記の結論が得られた。

1. 軸力の大きさと鋼管の幅 $D$ と板厚 $t$ との比 $D / t$ は，軸力と曲げを受けるコンクリート充てん角形鋼管柱 の塑性域に扔ける挙動, 特に曲げモーメント・曲率関係 の耐力以後の性状に大きな影響を及ぼす。すなおち， $D / t$ が 24 の柱法塑性域においても曲げモーメントの低 下が見られないが， $D / t$ が 44 の柱㤝高軸力下に扔いて 脆性的な挙動を示す (図 7 参照)。

2. 設計上重要な曲げ終局強度は，焼鈍した鋼管を用 いた柱に対しては, 本論で述べる簡単な計算法により精 度よく算定出来る（図 $10 \mathrm{a}$ 参照）。ただし, 本計算法の 適用範囲恰軸力が $0.5 N_{0}\left(N_{0}={ }_{s} A{ }_{s} \sigma_{y}+{ }_{c} A{ }_{c} \sigma_{B}\right)$ 以下 の場合とする。この適用範囲は，設計する上では支障と ならないと考えられる。 